\title{
Shielding Volume Reduction in a High Dose Rate Brachytherapy Room
}

\section{Reducción de Volumen de Blindaje en una Sala de Braquiterapia de Alta Tasa de Dosis}

\author{
S. González-Guzmán', H. M. Montenegro-Monroy', J. Pérez-Honorato², M. A. Martínez-Flores³, F. Miranda-Suárez² \\ Universidad Autónoma del Estado de México \\ ${ }^{2}$ Centro Oncológico Estatal del Instituto de Seguridad Social del Estado de México y Municipios (ISSEMyM) \\ 32Dirección de Gestión y Control del Instituto de Seguridad Social del Estado de México y Municipios (ISSEMyM)
}

\begin{abstract}
This paper describes a method to reduce the shielding thickness in a high dose brachytherapy treatment room, with an Iridium-192 source, using the protocols established by the International Atomic Energy Agency in its Safety Report No. 47; calculating the volume of shielding material, without failing to comply with the radiation safety parameters established by the General Radiation Safety Regulations and regulations in force by the Comisión Nacional de Seguridad Nuclear y Salvaguardias, which acts as the regulatory body for the use of radioactive sources in Mexico. The shielding of the walls was determined as a function of room design, source activity, workload, use factor, number of weekly treatments, treatment time, and shielding material properties. The results show that the shielding volume can be reduced by $\mathbf{1 9 . 5 9 2 \%}$ and $\mathbf{2 0 . 7 2 7 \%}$ for five-point and eleven-point fractionation, respectively, for a Brachytherapy room with a maze.
\end{abstract}

KEYwORDS: Shielding, Brachytherapy, Radiation Protection 


\section{RESUMEN}

El presente trabajo describe un método para reducir el grosor de blindaje en una sala de tratamiento de Braquiterapia de alta dosis con fuente de Iridio-192, utilizando los protocolos establecidos por el Organismo Internacional de Energía Atómica en su Informe de Seguridad No. 47; calculando el volumen de material de blindaje, sin incumplir con los parámetros de seguridad radiológica que establece el Reglamento General de Seguridad Radiológica y normatividad vigente por la Comisión Nacional de Seguridad Nuclear y Salvaguardias, quien funge como órgano regulador para el uso de fuentes radiactivas en México. Por lo que se determinó el grosor de las paredes en función al diseño de la sala, ubicación y actividad total de la fuente, así como, factor de ocupación en áreas adyacentes carga de trabajo, factor de uso, número de tratamientos semanales, tiempo promedio de tratamiento y propiedades del material de blindaje. Mediante estos cálculos, se determinó que el volumen de blindaje se puede reducir un 19.592\% y $20.727 \%$ para el fraccionamiento en cinco y once puntos, respectivamente, para una sala de Braquiterapia con laberinto.

PALAbras ClaVe: Blindaje, Braquiterapi, Protección Radiológica

\section{Corresponding author}

TO: Jonathan Pérez Honorato

INSTITUTION: Centro Oncológico Estatal del Instituto de Seguridad Social del Estado de México y Municipios (ISSEMyM)

ADDRESS: Av. Solidaridad Las Torres \#101, Col. Del

Parque, C. P. 50180, Toluca, Estado de México, México

E-MAIL: jonathanperezhonorato@yahoo.com.mx

\section{Received:}

24 June 2021

\section{Accepted:}

3 December 2021 


\section{INTRODUCTION}

Radiation protection (RP) focuses on the prevention of stochastic and deterministic damage caused by ionizing radiation to workers, the public, and the environment, without interfering with the exposure processes associated with a benefit, ranging from electric power generation to applications in medicine, industry, and agriculture ${ }^{[1]}[2][3]$.

$\mathrm{RP}$ is the responsibility of each country; however, there are international organizations such as the International Atomic Energy Agency (IAEA) and the International Commission on Radiological Protection (ICRP), which issue recommendations on radioprotection to reduce risks and prevent accidents, respond to emergencies associated with radioactive sources and seek to mitigate harmful effects associated with radiological exposure practices; environmental, occupational, or public ${ }^{[3]}{ }^{[4]}$.

It is important to mention that the RP is based on the principles of:

- Justification: Any practice involving exposure to ionizing radiation should produce more benefit than harm ${ }^{[1]}$.

- Optimization: All radiation exposure should be kept As Low As Reasonably Achievable (ALARA Principle) ${ }^{[1]}$.

- Dose limits: applicable for planned and justified radiation exposure ${ }^{[1]}$.

The first two are aimed at the use of the radioactive source, and the third one, for exposed personnel and the public ${ }^{[5]}$, regulating the dose limits in force. In Mexico, the Comisión Nacional de Seguridad Nuclear $y$ Salvaguardias (CNSNS -National Commission for Nuclear Safety and Safeguards-) is the regulatory body for the use of radioactive sources, and the effective dose equivalent were published in the Reglamento General de Seguridad Radiológica (General Regulation of Radiological Safety). These values and the recommended values by the ICRP are measured in millisievert (mSv) and shown in Table 1.

\section{TABLE 1. Summary of effective exposure} limits in blanned situations ${ }^{[8][9]}$.

\begin{tabular}{|c|c|c|}
\hline Dose limit & $\begin{array}{c}\text { Occupationally } \\
\text { exposed } \\
\text { personnel }\end{array}$ & Public \\
\hline \multirow{2}{*}{$\begin{array}{l}\text { Reglamento } \\
\text { General de } \\
\text { Seguridad } \\
\text { Radiológica }\end{array}$} & $\begin{array}{c}50 \mathrm{mSv} / \text { year } \\
\text { for stochastic } \\
\text { effects }\end{array}$ & $\begin{array}{l}5 \mathrm{mSv} / \text { year for } \\
\text { stochastic effects }\end{array}$ \\
\hline & $\begin{array}{l}500 \mathrm{mSv} / \text { year } \\
\text { for deterministic } \\
\text { effects }\end{array}$ & $\begin{array}{c}50 \mathrm{mSv} / \text { year for } \\
\text { deterministic } \\
\text { effects }\end{array}$ \\
\hline ICRP & $\begin{array}{l}100 \mathrm{mSv} / 5 \text { years } \\
\text { conditional on not } \\
\text { exceeding } 50 \mathrm{mSv} \\
\text { per year }\end{array}$ & $1 \mathrm{mSv} /$ year \\
\hline Crystalline & $150 \mathrm{mSv}$ & $5 \mathrm{mSv}$ \\
\hline Skin & $500 \mathrm{mSv}$ & $50 \mathrm{mSv}$ \\
\hline Hands and feet & $500 \mathrm{mSv}$ & - \\
\hline
\end{tabular}

Also, there are RP factors or practical RP methods ${ }^{[6]}$, which are:

- Time: The less time an individual is exposed to a radiation source, the lowest dose absorbed ${ }^{[7]}$.

- Distance: Every individual should be as far away as possible from the radiation source, according to the inverse square law of distance, which indicates that it is inversely proportional to the square of the distance from the source ${ }^{[4]}[$ 7].

- Shielding: Barrier between the source and the individual that reduces the intensity of ionizing radiation ${ }^{[7]}$.

These factors should be considered to optimize the RP design ${ }^{[6]}$. Regarding shielding, it depends on activity, type of radiation and energy emitted by the source, 
which is directly related to the type of particles released by the radionuclide (emissions $\alpha, \beta+, \beta$-, $\gamma$, etc.) [7], as well as the density and thickness of the material. Nowadays, the most used materials are concrete, lead, and steel [7] [10], whose description and density are shown in Table 2.

TABLE 2. Examples of radiological

shielding materials ${ }^{[11]}$.

\begin{tabular}{|c|l|}
\hline Material & \multicolumn{1}{c|}{ Comments } \\
\hline Concrete & Its density varies with mineral content. \\
\hline Steel /Lead & $\begin{array}{l}\text { It is normally used as supplementary } \\
\text { shielding. }\end{array}$ \\
\hline
\end{tabular}

Regarding medical use, radioactive sources are used in diagnosis, treatment ${ }^{[1]}$, and theragnostic ${ }^{[12]}$. Particularly in treatments, there are teletherapy and brachytherapy.

Brachytherapy is a treatment in which radioactive sources are placed at a short distance from the tumor. It is classified according to dose rate or how quickly the dose is delivered to the patient: low, medium, and high ${ }^{[13]}$. In the case of High Dose Rate Brachytherapy (HDR-B), the most radioactive isotopes used are Cobalt-60 $\left({ }^{60} \mathrm{Co}\right)$ and Iridium-192 $\left({ }^{192} \mathrm{Ir}\right){ }^{[11]}$. Particularly, ${ }^{192}$ Ir has a half-life of 73,829 days and decays $95.35 \%$ by particle emission $\beta$ and $4.65 \%$ by Electronic Capture (EC) to excited states of Platinum-192 ( $\left.{ }^{192} \mathrm{Pt}\right)$ and Osmium-192 ( ${ }^{192} \mathrm{Os)}$ respectively. Afterwards, they decay by emission $\gamma$ until they reach stability (Figure 1) ${ }^{[14]}{ }^{[15]}$. Exposure to high levels of $\gamma$-rays cause harmful effects (for example cancer), which is why a barrier is used to attenuate them (mainly by photoelectric effect and Compton effect) ${ }^{[16]}$.

Shielding depends on the design of the HDR-B treatment room. Therefore, the IAEA suggests a room design with a doorless maze for ${ }^{60} \mathrm{Co}$ radioactive source, includes a control area, preparation/procedure room,

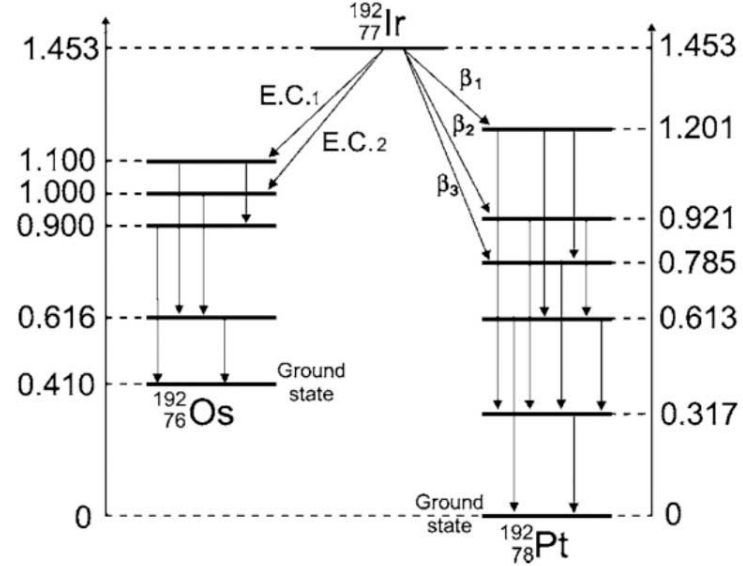

FIGURE 1. ${ }^{192}$ Ir decay diagram by particle emission and EC [15].

recovery area, sluice room, and image processing area (Figure 2) ${ }^{[17]}$. The dimensions for the width of the maze should be 1.8 meters $(\mathrm{m})$, the internal ones $4 \mathrm{~m}$ long by $4 \mathrm{~m}$ wide (Figure 2), and a height of 3 to $3.6 \mathrm{~m}$. The above, assuming the use of fluoroscopy equipment for applicator placement ${ }^{[11]}$, although Computed Tomography (CT) and Magnetic Resonance Imaging (MRI) simulation is also used ${ }^{[17]}$.

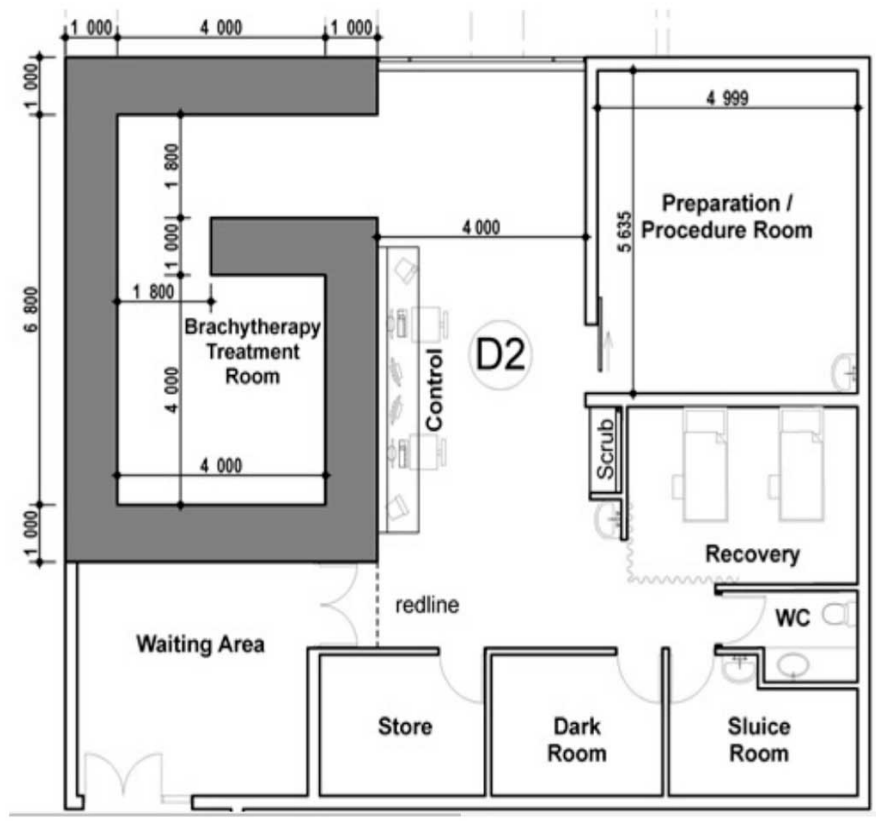

FIGURE 2. Brachytherapy treatment room for ${ }^{60} \mathrm{Co}$ source suggested by IAEA: dimensions and adjoining areas ${ }^{[17]}$. 


\section{Calculation of primary barriers}

IAEA Safety Report Series No. 47 (SRS-47) describes a method for calculating shielding thicknesses in walls, floor, and roof and considerations as primary barriers (shielding where useful radiation beam hits directly). This method starts from the calculation of the attenuation required by the barrier (B) given a dosimetry shielding point that is at a certain distance from the source (d) ${ }^{[4]}{ }^{[11][18]}$. Thus, B is determined from Equation (1):

$$
\mathrm{B}=\frac{\mathrm{Pd}^{2}}{\mathrm{WUT}}
$$

Where $P$ is the design limit measured in $\mu \mathrm{Sv}$ week $^{-1}, W$ is the workload in micro grays per square meter week ${ }^{-1}$ ( $\mu \mathrm{Gy} \mathrm{m} 2$ week $^{-1}$ ), $U$ is the use factor, and $T$ is the occupancy factor of adjacent areas ${ }^{[11]}$.

Concerning $P$, it must ensure compliance with the permissible exposure dose limits for adjacent areas. The classification of the adjacent areas is:

- Controlled: areas with specific protective measures to control potential exposures under normal working conditions. The limit is $P$ equal to 120 microsievert per week $\left(\mu \mathrm{Sv}_{\text {week }}\right)^{-11]}{ }^{[16]}$.

- Uncontrolled (public): areas that are not designated as controlled but are under review. The design limit is $6 \mu \mathrm{Sv}$ week $^{-1}{ }^{[11]}[16]$.

About $W$, it refers to the dose administered per treatment each time (usually in one week) ${ }^{[4]}{ }^{[11]}$. It is calculated by the Equation (2) ${ }^{[11]}$ :

$$
W=R A K R \cdot A \cdot t \cdot n
$$

Where RAKR is the Reference Air Kerma Rate for a source of unit activity at one-meter distance modified by attenuation and scattering in the air ${ }^{[16]} ; A$ is the total source activity measured in becquerels $(\mathrm{Bq}) ; t$ is the average treatment duration in hours, and $\mathrm{n}$ is the number of treatments per week ${ }^{[11]}$.

According to the American Association of Medical Physicists Publication No. 21 (AAPM-21), $W$ is determined by the Equation (3) ${ }^{[19]}$ :

$$
\mathrm{W}=\mathrm{S}_{\mathrm{k}} \cdot \mathrm{t} \cdot \mathrm{n}
$$

Where $S_{k}$ is the air kerma strength of the source in units of $U$ o $\left(\mu \mathrm{Gy} \mathrm{m} \mathrm{m}^{2}\right) / \mathrm{h}$ and it is equivalent to the product of $R A K R$ times $A^{[19]}$.

For the $T$ factor, it indicates the average fraction of time that a person is mostly exposed to adjacent area where the source is in use. Table 3 shows the value for each area according to NCRP Report No. 49 (NCRP-49) ${ }^{[4]}$ [10] [11].

\section{TABLE 3. Occupancy factor T recommended by the NCRP-49 [10] [11].}

\begin{tabular}{|l|c|}
\hline \multicolumn{1}{|c|}{ Type of area } & T \\
\hline $\begin{array}{l}\text { Offices, laboratories, shops, children's } \\
\text { play areas, nurse's stations, staff rooms. } \\
\text { Control room, patient rooms. }\end{array}$ & 1 \\
\hline Corridors. & $1 / 4$ \\
\hline $\begin{array}{l}\text { Waiting rooms, toilets, stairways, } \\
\text { unattended elevators, vehicular traffic. }\end{array}$ & $1 / 16$ \\
\hline
\end{tabular}

It is important to mention that for HDR-B, the sources are isotropic, i.e., they are not collimated, and their emissions are in all directions. In this sense, the $U$ factor will always be equal to $1^{[4][11]}$.

It is also recommended the use of the Tenth Value Layer (TVL) and Half Value Layer (HVL), which reduce the radiation intensity by a factor of one tenth and one half of the initial intensity, respectively, whose thickness is specific for each material and radionuclide ${ }^{[11]}$. The number of TVL that produces a transmission factor B is calculated from the Equation (4) ${ }^{[11]}$ : 


$$
\mathrm{TVL}=\log _{10}\left(\frac{1}{\mathrm{~B}}\right)
$$

So, the barrier thickness (Et) is obtained by multiplying the TVL times the TVL value of the material (TVLm) ${ }^{[11]}$, as shown in the Equation (5):

$$
\mathrm{Et}=\mathrm{TVL} \cdot \mathrm{TVLm}
$$

\section{Calculation of secondary barriers}

In addition, secondary radiation must be considered, especially that transmitted into the maze. For which, the factor B for the secondary barriers (barriers not in direct contact with the radiation beam from the source), is calculated from Equation (6) ${ }^{[11]}$ :

$$
B=\frac{P_{\text {sca }}^{2} d_{s e c}^{2}}{\alpha W T\left(\frac{F}{400}\right)}
$$

Where $\mathrm{d}_{\text {sca }}$ is the distance from the radiation source to the patient in meters $(m) ; d_{\text {sec }}$ is the distance from the patient to the point of interest in $m$; $\alpha$ is the beam energy scattering fraction and scattering angle in $\mathrm{d}_{\text {sca }} ; F$ is the incident field area over the patient in square centimeters $\left(\mathrm{cm}^{2}\right)$.

\section{MATERIALS AND METHODS}

The method consists of three stages: the first is to identify the room design data, source characteristics, design limits and shielding material. The second stage is to determine the number of dosimetric point per wall and roof, calculating the shielding using the IAEA SRS-47 method (described previously) for each point, and obtain the area and volume of each barrier. The last stage involves calculating and analyzing the shielding reduction percentages (Figure 3 ).

First, the data of the HDR-B room are identified, considering the design, dimensions, and adjacent areas shown in Figure 4, having as primary barriers wall A, $\mathrm{B}, \mathrm{D}$, and $\mathrm{E}$, and a distinction of primary and secondary barriers, on wall $\mathrm{C}$ and the roof.

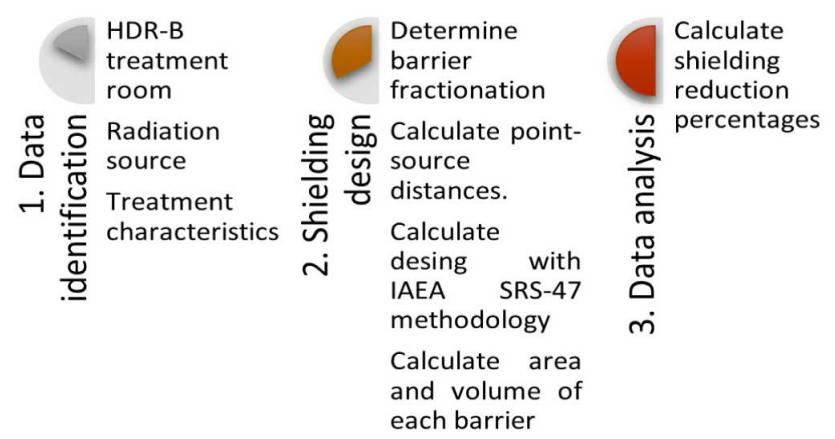

FIGURE 3. Method for fractional calculation of the shielding of an HDR-B room.

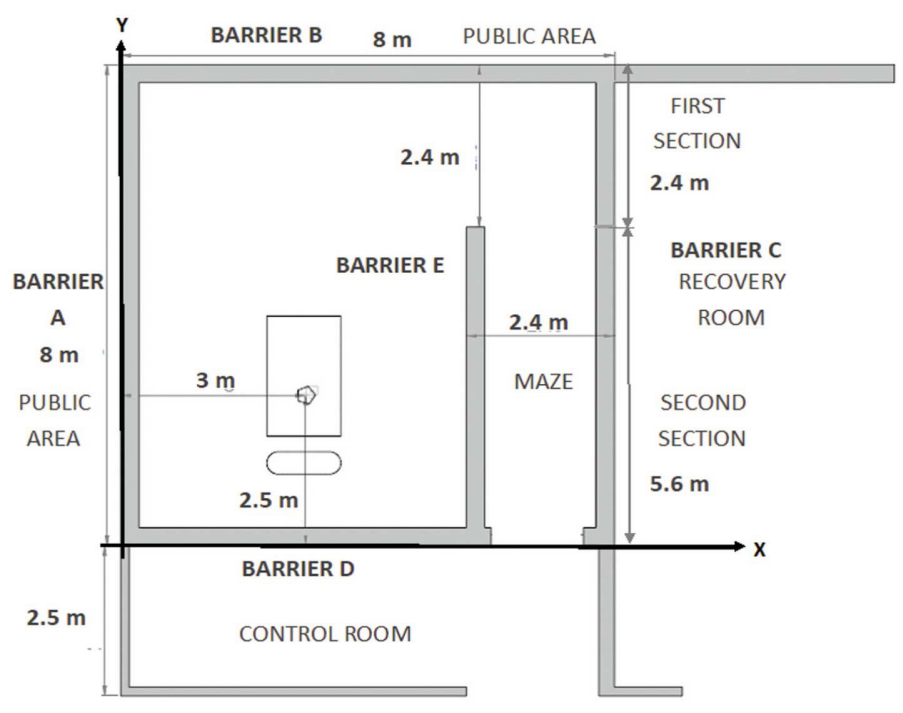

FIGURE 4. Representation of the dimensions and adjoining areas of the HDR-B room, in $\mathrm{x}-\mathrm{y}$ view.

For this case, we consider the use of an ${ }^{192}$ Ir source with a nominal activity of 370 Gigabecquerel (GBq), RAKR of $0.111 \mu \mathrm{Gy} \cdot \mathrm{MBq}^{-1} \cdot \mathrm{m}^{2} \cdot \mathrm{h}^{-1}[11]$, total activity (A) of $555 \mathrm{GBq}{ }^{[20]}$, a workload $(n)$ of 30 treatments per week, with an average treatment duration $(t)$ of 10 minutes ( 0.167 hours) to deliver an absorbed dose of 7.5 Gy, to the prescription point per treatment and concrete as shielding material, whose TVL value for this source is $0.152 \mathrm{~m}^{[11]}$.

Also, the value for the factor $\mathrm{T}$ and the design limit $\mathrm{P}$ is established according to the adjacent area and NCRP 49 (values shown in Table 3) ${ }^{[10]}$. The assignment of these values is shown in Table 4. 
TABLE 4. Summary of values used according to the NCRP.

\begin{tabular}{|c|c|c|c|c|}
\hline Barrier & $\begin{array}{c}\text { Adjacent } \\
\text { area }\end{array}$ & $\mathbf{T}$ & $\begin{array}{c}\text { Type } \\
\text { of area }\end{array}$ & $\begin{array}{c}\mathbf{P} \\
{\left[\boldsymbol{\mu} \mathbf{S v}_{\text {week }} \mathbf{-}^{-1}\right]}\end{array}$ \\
\hline A & Garden & $1 / 16$ & Uncontrolled & 6 \\
\hline B & Garden & $1 / 16$ & Uncontrolled & 6 \\
\hline C & $\begin{array}{c}\text { Recovery } \\
\text { room }\end{array}$ & $1 / 16$ & Uncontrolled & 6 \\
\hline D & $\begin{array}{c}\text { Control } \\
\text { room }\end{array}$ & 1 & Controlled & 120 \\
\hline E & Maze & $1 / 16$ & Uncontrolled & 6 \\
\hline Roof & None & $1 / 16$ & Uncontrolled & 6 \\
\hline
\end{tabular}

For the second stage, the barriers A, B, D and E are divided into 4 (5 points) and 10 (11 points) equal parts (see example in Figure 5, for 5 points), where for each division point (dosimetric points) and distances closer to the source ( $\mathrm{dA}, \mathrm{dB}, \mathrm{dD}$ and $\mathrm{dE}$ ) the following calculations are performed:

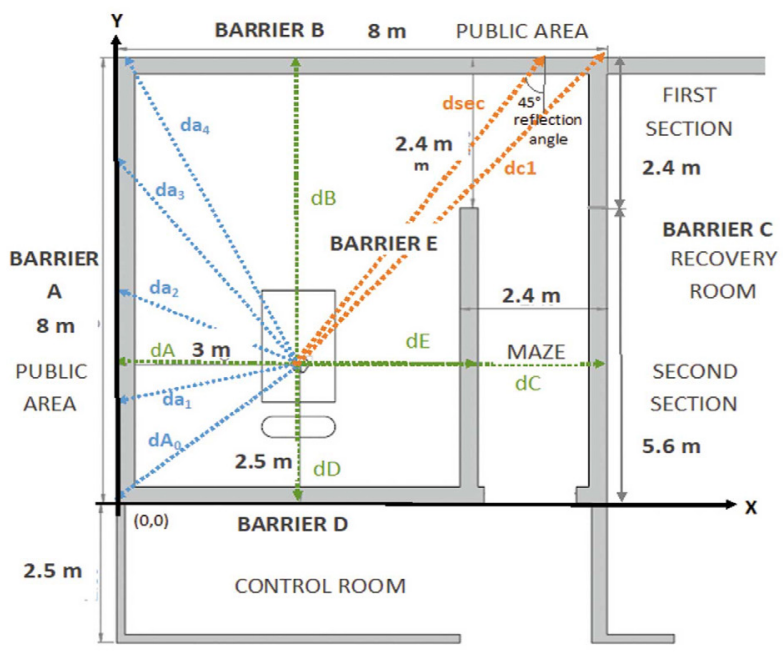

FIGURE 5. Location of 5 dosimetric points on barrier $A$, as well as the closest distances from the source to the walls of the HDR-B treatment room.

First, the distances of the points to the source (distance between two points) are calculated, using the Equation (7) ${ }^{[21]}$.

$$
d_{n}=\sqrt{\left(x-x_{0}\right)^{2}+\left(y-y_{0}\right)^{2}+\left(z-z_{0}\right)^{2}}
$$

For this purpose, the positions $(\mathrm{x}, \mathrm{y}, \mathrm{z})$ of the dosimetric points on the cartesian plane, represented by the HDR-B room, are considered. Which has origin $(0,0)$ at the lower left and the source position at $\left(\mathrm{x}_{0}=3, \mathrm{y}_{0}=2.5\right.$, $\left.z_{0}=1.1\right)$ (Figure 4).

Then, the $W$ factor is calculated by substituting the values of RAKR, $A, t$, and $n$, in the Equation (2), which results:

$$
\begin{gathered}
W=\left(0.111 \mu G y m^{2} \cdot M B q^{-1} h^{-1}\right) \\
\left(555 x 10^{3} M B q\right)(0.167 \mathrm{~h})\left(30{\text { treatments } \left.\text { week }^{-1}\right)}^{\mathrm{W}=308,641.050 \mu \mathrm{Gy} \mathrm{m}^{2} \text { week }^{-1}}\right.
\end{gathered}
$$

The shielding thickness is then calculated for each of the points of each barrier, substituting the values of $P$, $W, U, T$, and $d$ the in Equation (1), obtaining:

$$
B=\frac{\left(6 \mu \mathrm{Sv} \text { week }^{-1}\right)\left(d^{2}\right)}{\left(308,641.050 \mu \mathrm{Gy} m^{2} \cdot \text { week }^{-1}\right)(1)(T)}
$$

The obtained value of $B$ is then substituted into the Equation (4) to calculate the number of TVL:

$$
T V L=\log _{10}\left(\frac{1}{B}\right)
$$

The result and the TVL value of the concrete for ${ }^{192} \mathrm{Ir}$ are substituted in the Equation (5), resulting:

$$
E t=(\mathrm{TVL})(0.152 \mathrm{~m})
$$

Once all the points of barriers A, B, D, and $\mathrm{E}$ have been obtained, the area of each barrier is calculated by obtaining the areas of the rectangular trapezoids $\left(a_{\text {tr }}\right)$ formed by the thicknesses of each dosimetric, as shown in Figure 6. This calculation is performed with the Equation (8) ${ }^{[22]}$ :

$$
a_{t r}=\frac{\left(B_{t}+b\right) * h}{2}
$$


Where $B_{t}$ is the major base (lower thickness), and $b$ is the minor base (upper thickness), and $h$ is the height (dosimetric point spacing).

The sum of the areas of the rectangular trapezoids provides the area of each barrier. Subsequently, it is multiplied by the height of the room, which is 3.5 meters, to obtain the volume.

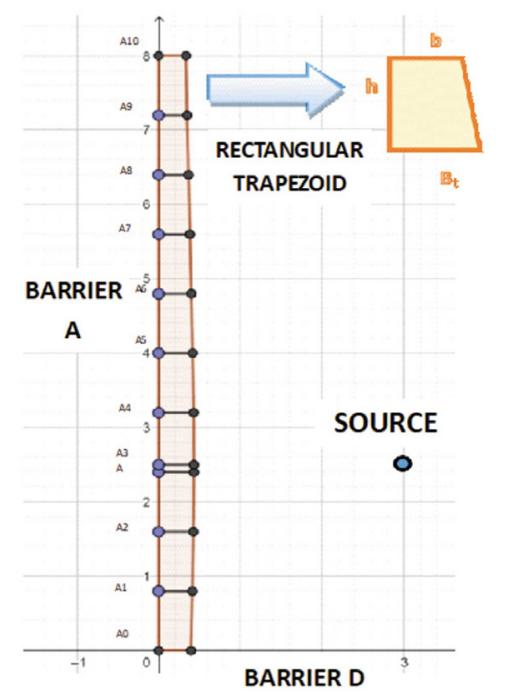

FIGURE 6. Rectangular trapezoid formed by the point $\mathrm{A} 9$ and $\mathrm{A} 10$ of the 11-point fractionation of the barrier $\mathrm{A}$.

In the case of the wall $\mathrm{C}$, it is divided into two sections (Figure 4). For the first section, the distance dc1 is considered and the shielding thickness is calculated using the calculations described for barriers A, B, D, and $\mathrm{E}$. For the second section, the distance from the source to the middle of the maze on wall B (dsec) having coordinates $(6.8,8)$ (Figure 4 ) is calculated using the Equation (7), resulting:

$$
d_{s e c}=\sqrt{(6.8-3)^{2}+(8-2.5)^{2}}=6.685 \mathrm{~m}
$$

For this case, we considered the $d_{\text {sca }}$ value of $1.5 \mathrm{~m}$ and a maximum $\mathrm{F}$ of $400 \mathrm{~cm}^{2}$ and a reflection angle of $45^{\circ}$ for $60 \mathrm{Co}(\alpha)$ of $0.0037^{[11]}$; these values and the values of $T, P$, and $W$ (calculated previously) are substituted in Equation (6) to obtain the factor B, resulting:

$$
B=\frac{\left(6 \frac{\mu \mathrm{Sv}}{\mathrm{sem}}\right)(1.5 \mathrm{~m})^{2}(6.685 \mathrm{~m})^{2}}{(0.0037)\left(308,641.050 \mu \mathrm{Gy} \mathrm{m} \mathrm{m}^{2} \text { week }^{-1}\right)(1)\left(\frac{400}{400}\right)}
$$

Then, the value of $B$ is substituted in the Equation (4) and subsequently, Equation (5) are used to obtain the final thickness. The area is calculated by multiplying the width of the barrier ( $2.4 \mathrm{~m}$ for the first section and $5.6 \mathrm{~m}$ times the second section) and the sum of these are multiplied times the height $(3.5 \mathrm{~m})$ to obtain the volume.

For the roof shield calculation, it is divided into two sections (Figure 7).

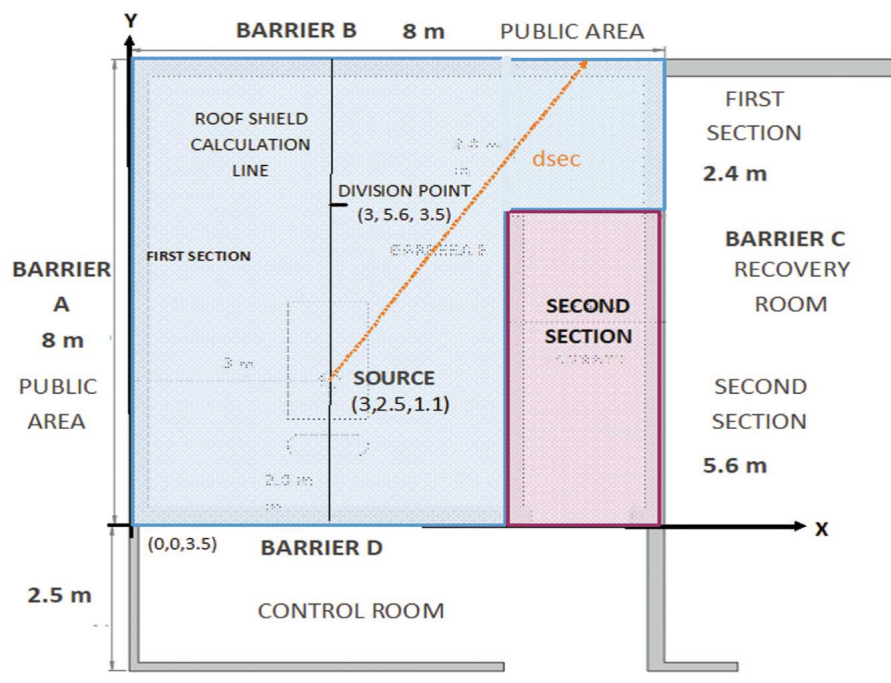

FIGURE 7. Dosimetric points calculated on the roof of the HDR-B room.

In the case of the first section, the fractionation into 5 and 11 divisions is performed on the position of the source on the $\mathrm{x}$-axis (indicated with a black line in Figure 7). The calculations of the distances are carried out in the dimensions (x, y, z) with the Equation (7), the shortest distance to the source $(3,2.5,3.5)$, and the position $(3,5.6,3.5)$ are also considered.

Then, for each of the distances obtained, the thickness is calculated using the Equations (1), (4), and (5). 
To obtain the area, Equation (8) is used in the same way with barriers A, B, D, and E. These areas are multiplied by the width of each section and the result is multiplied by the length of the room ( $5.6 \mathrm{~m}$ or $8 \mathrm{~m}$ ) to obtain the volume.

The second section is analyzed as a secondary barrier, so the distance from the point $d(6.8,8,3.5)$ (Figure 7) is calculated using the Equation (7). Subsequently, $B$ is calculated with the Equation (6), considering the same values of $d, F$, and $\alpha$. The shielding thickness is calculated using the Equations (4) and (5).

The area is obtained by multiplying the thickness times the length of the section $(5.6 \mathrm{~m})$. The result is multiplied by the width of the section $(2.4 \mathrm{~m})$ to obtain the volume.

As for the reference volume values, they are calculated by multiplying the thickness of the points $\mathrm{dA}$, $\mathrm{dB}, \mathrm{dD}, \mathrm{dC}, \mathrm{dE}$ and $\mathrm{dT}$, times the length of each barrier (area), the result is multiplied by the height.

For the third stage, the percentage of reduction is calculated by comparing the volume calculated at one point in each of the barriers against this obtained for 5 and 11 points.

Also, the geometric mean $(G)$ is calculated at the reduction percentages per barrier, which is defined as the root- nth $(\mathrm{N})$ of the product of all the elements $(\mathrm{n})$, represented by the Equation (9) ${ }^{[23]}[24]$ :

$$
G=\sqrt[N]{x_{1} * x_{2} \ldots * x_{n}}
$$

As for the total percentage of the reduced shielding of the HDR-B room, it is calculated by adding the volumes of all barriers at one, 5, and 11 points. Subsequently, a comparison is made of the required shielding volume at one point vs. 5 points and one point vs. 11 points.

\section{RESULTS AND DISCUSSION}

From the previous study, Tables 5 and 6 were obtained as a result of the fractionation of barriers $\mathrm{A}, \mathrm{B}, \mathrm{D}$, and $\mathrm{E}$ for 5 and 11 points, where $x$ and $y$ indicate the positions of each dosimetric point, $d$ is the calculated distance from the point to the source measured in meters, Et is the required shielding thickness in meters, a is the area obtained from each rectangular trapezoid, ac is the sum of the areas of the rectangular trapezoids comprising the barrier.

TABLE 5. Shielding for barriers A, B, D and E, for 5 points.

\begin{tabular}{|c|c|c|c|c|c|c|c|c|}
\hline Barrier & $\mathbf{N}^{\circ}$ & $\mathbf{x}$ & $\mathbf{y}$ & $\begin{array}{c}\text { d } \\
{[\mathbf{m}]}\end{array}$ & $\begin{array}{c}\text { Et } \\
{[\mathbf{m}]}\end{array}$ & $\underset{\left[\mathrm{m}^{2}\right]}{\operatorname{atr}}$ & $\underset{\left[\mathbf{m}^{2}\right]}{\mathbf{a c}}$ & $\begin{array}{c}\text { Volume } \\
{\left[\mathbf{m}^{3}\right]}\end{array}$ \\
\hline \multirow{6}{*}{ A } & 0 & 0.000 & 0.000 & 3.905 & 0.350 & & \multirow{6}{*}{2.831} & \multirow{6}{*}{9.909} \\
\hline & 1 & 0.000 & 2.000 & 3.041 & 0.383 & 0.733 & & \\
\hline & $\mathrm{dA}$ & 0.000 & 2.500 & 3.000 & 0.383 & 0.192 & & \\
\hline & 2 & 0.000 & 4.000 & 3.354 & 0.383 & 0.575 & & \\
\hline & 3 & 0.000 & 6.000 & 4.610 & 0.328 & 0.711 & & \\
\hline & 4 & 0.000 & 8.000 & 6.265 & 0.292 & 0.620 & & \\
\hline \multirow{6}{*}{ B } & 0 & 0.000 & 8.000 & 6.265 & 0.292 & & \multirow{6}{*}{2.369} & \multirow{6}{*}{8.292} \\
\hline & 1 & 2.000 & 8.000 & 5.590 & 0.304 & 0.596 & & \\
\hline & $\mathrm{dB}$ & 3.000 & 8.000 & 5.500 & 0.311 & 0.308 & & \\
\hline & 2 & 4.000 & 8.000 & 5.590 & 0.304 & 0.308 & & \\
\hline & 3 & 6.000 & 8.000 & 6.265 & 0.292 & 0.596 & & \\
\hline & 4 & 8.000 & 8.000 & 7.433 & 0.269 & 0.561 & & \\
\hline \multirow{6}{*}{ D } & 0 & 0.000 & 0.000 & 3.905 & 0.338 & & \multirow{6}{*}{2.131} & \multirow{6}{*}{7.459} \\
\hline & 1 & 1.400 & 0.000 & 2.968 & 0.383 & 0.505 & & \\
\hline & 2 & 2.800 & 0.000 & 2.508 & 0.410 & 0.555 & & \\
\hline & $\mathrm{dD}$ & 3.000 & 0.000 & 2.500 & 0.410 & 0.082 & & \\
\hline & 3 & 4.200 & 0.000 & 2.773 & 0.383 & 0.476 & & \\
\hline & 4 & 5.600 & 0.000 & 3.607 & 0.350 & 0.513 & & \\
\hline \multirow{6}{*}{ E } & 0 & 5.600 & 0.000 & 3.607 & 0.364 & & \multirow{6}{*}{2.184} & \multirow{6}{*}{7.644} \\
\hline & 1 & 5.600 & 1.400 & 2.823 & 0.410 & 0.542 & & \\
\hline & $\mathrm{dE}$ & 5.600 & 2.500 & 2.600 & 0.410 & 0.451 & & \\
\hline & 2 & 5.600 & 2.800 & 2.617 & 0.410 & 0.123 & & \\
\hline & 3 & 5.600 & 4.200 & 3.106 & 0.383 & 0.555 & & \\
\hline & 4 & 5.600 & 5.600 & 4.046 & 0.350 & 0.513 & & \\
\hline
\end{tabular}

According to Figure 8, we can observe that in barrier $\mathrm{A}$, there is a decreasing trend in the thickness of the shielding thickness from $10.724 \mathrm{~m}^{3}$ of concrete calculated for one point to $9.909 \mathrm{~m} 3$ for 5 points and $9.916 \mathrm{~m}^{3}$ for 11 points. This behavior represents a percentage decrease of $\mathbf{7 . 6 0 0 \%}$ and $\mathbf{7 . 5 3 5 \%}$ (Table 7), respectively.

Also, in barrier there is B a decrease from $8.708 \mathrm{~m}^{3}$ at one point to $8.292 \mathrm{~m}^{3}$ at 5 points and $8.295 \mathrm{~m}^{3}$ at 11 points (Figure 8). The percentage decrease is $\mathbf{4 . 7 7 7 \%}$ and $\mathbf{4 . 7 4 3 \%}$, respectively (Table 7 ). 
TABLE 6. Shielding for barriers A, B, D and E, for 11 points.

\begin{tabular}{|c|c|c|c|c|c|c|c|c|}
\hline Barrier & $\mathbf{N}^{\circ}$ & $\mathbf{x}$ & $\mathbf{y}$ & $\begin{array}{c}\text { d } \\
{[\mathrm{m}]}\end{array}$ & $\begin{array}{c}\text { Et } \\
{[\mathrm{m}]}\end{array}$ & $\underset{\left[\mathrm{m}^{2}\right]}{\text { atr }}$ & $\begin{array}{c}\mathbf{a c} \\
{\left[\mathrm{m}^{2}\right]}\end{array}$ & $\begin{array}{c}\text { Volume } \\
{\left[\mathbf{m}^{3}\right]}\end{array}$ \\
\hline \multirow{12}{*}{ A } & 0 & 0.000 & 0.000 & 3.905 & 0.350 & & \multirow{12}{*}{2.833} & \multirow{12}{*}{9.916} \\
\hline & 1 & 0.000 & 0.800 & 3.448 & 0.364 & 0.286 & & \\
\hline & 2 & 0.000 & 1.600 & 3.132 & 0.383 & 0.299 & & \\
\hline & 3 & 0.000 & 2.400 & 3.002 & 0.383 & 0.306 & & \\
\hline & $\mathrm{dA}$ & 0.000 & 2.500 & 3.000 & 0.383 & 0.038 & & \\
\hline & 4 & 0.000 & 3.200 & 3.081 & 0.383 & 0.268 & & \\
\hline & 5 & 0.000 & 4.000 & 3.354 & 0.383 & 0.306 & & \\
\hline & 6 & 0.000 & 4.800 & 3.780 & 0.364 & 0.299 & & \\
\hline & 7 & 0.000 & 5.600 & 4.314 & 0.338 & 0.281 & & \\
\hline & 8 & 0.000 & 6.400 & 4.920 & 0.319 & 0.263 & & \\
\hline & 9 & 0.000 & 7.200 & 5.576 & 0.304 & 0.249 & & \\
\hline & 10 & 0.000 & 8.000 & 6.265 & 0.292 & 0.238 & & \\
\hline \multirow{12}{*}{ B } & 0 & 0.000 & 8.000 & 6.265 & 0.292 & & \multirow{12}{*}{2.370} & \multirow{12}{*}{8.295} \\
\hline & 1 & 0.800 & 8.000 & 5.924 & 0.298 & 0.236 & & \\
\hline & 2 & 1.600 & 8.000 & 5.675 & 0.304 & 0.241 & & \\
\hline & 3 & 2.400 & 8.000 & 5.533 & 0.304 & 0.243 & & \\
\hline & $\mathrm{dB}$ & 3.000 & 8.000 & 5.500 & 0.311 & 0.185 & & \\
\hline & 4 & 3.200 & 8.000 & 5.504 & 0.311 & 0.062 & & \\
\hline & 5 & 4.000 & 8.000 & 5.590 & 0.304 & 0.246 & & \\
\hline & 6 & 4.800 & 8.000 & 5.787 & 0.304 & 0.243 & & \\
\hline & 7 & 5.600 & 8.000 & 6.084 & 0.292 & 0.238 & & \\
\hline & 8 & 6.400 & 8.000 & 6.466 & 0.287 & 0.232 & & \\
\hline & 9 & 7.200 & 8.000 & 6.920 & 0.277 & 0.226 & & \\
\hline & 10 & 8.000 & 8.000 & 7.433 & 0.269 & 0.218 & & \\
\hline \multirow{12}{*}{ D } & 0 & 0.000 & 0.000 & 3.905 & 0.338 & & \multirow{12}{*}{2.113} & \multirow{12}{*}{7.396} \\
\hline & 1 & 0.600 & 0.000 & 3.493 & 0.350 & 0.193 & & \\
\hline & 2 & 1.100 & 0.000 & 3.128 & 0.364 & 0.200 & & \\
\hline & 3 & 1.700 & 0.000 & 2.827 & 0.383 & 0.209 & & \\
\hline & 4 & 2.200 & 0.000 & 2.613 & 0.383 & 0.214 & & \\
\hline & 5 & 2.800 & 0.000 & 2.508 & 0.410 & 0.222 & & \\
\hline & $\mathrm{dD}$ & 3.000 & 0.000 & 2.500 & 0.410 & 0.082 & & \\
\hline & 6 & 3.400 & 0.000 & 2.526 & 0.410 & 0.148 & & \\
\hline & 7 & 3.900 & 0.000 & 2.664 & 0.383 & 0.222 & & \\
\hline & 8 & 4.500 & 0.000 & 2.905 & 0.383 & 0.214 & & \\
\hline & 9 & 5.000 & 0.000 & 3.227 & 0.364 & 0.209 & & \\
\hline & 10 & 5.600 & 0.000 & 3.607 & 0.350 & 0.200 & & \\
\hline \multirow{12}{*}{ E } & 0 & 5.600 & 0.000 & 3.607 & 0.364 & & \multirow{12}{*}{2.180} & \multirow{12}{*}{7.630} \\
\hline & 1 & 5.600 & 0.600 & 3.244 & 0.383 & 0.209 & & \\
\hline & 2 & 5.600 & 1.100 & 2.944 & 0.383 & 0.214 & & \\
\hline & 3 & 5.600 & 1.700 & 2.726 & 0.410 & 0.222 & & \\
\hline & 4 & 5.600 & 2.200 & 2.613 & 0.410 & 0.230 & & \\
\hline & $\mathrm{dE}$ & 5.600 & 2.500 & 2.600 & 0.410 & 0.107 & & \\
\hline & 5 & 5.600 & 2.800 & 2.617 & 0.410 & 0.123 & & \\
\hline & 6 & 5.600 & 3.400 & 2.739 & 0.410 & 0.230 & & \\
\hline & 7 & 5.600 & 3.900 & 2.962 & 0.383 & 0.222 & & \\
\hline & 8 & 5.600 & 4.500 & 3.268 & 0.383 & 0.214 & & \\
\hline & 9 & 5.600 & 5.000 & 3.635 & 0.364 & 0.209 & & \\
\hline & 10 & 5.600 & 5.600 & 4.046 & 0.350 & 0.200 & & \\
\hline
\end{tabular}

A similar case is barrier $\mathrm{D}$, the volume decreased from $8.036 \mathrm{~m}^{3}$ for one point to $7.459 \mathrm{~m}^{3}$ for 5 points and $7.396 \mathrm{~m}^{3}$ for 11 points (Figure 8), representing a decrease of $\mathbf{7 . 1 8 0 \%}$ and $\mathbf{7 . 9 6 4 \%}$ (Table 7), respectively.
TABLE 7. Percentage of volume reduced by barrier.

\begin{tabular}{|c|c|c|c|c|c|c|}
\hline $\begin{array}{c}\text { Number } \\
\text { of points }\end{array}$ & A [\%] & B [\%] & C [\%] & D [\%] & E [\%] & Roof [\%] \\
\hline 5 & 7.600 & 4.777 & 65.472 & 7.180 & 4.878 & 22.100 \\
\hline 11 & 7.535 & 4.743 & 65.472 & 7.964 & 5.052 & 24.901 \\
\hline
\end{tabular}

For barrier $\mathrm{E}$, the volume calculated for one point is $8.036 \mathrm{~m}^{3}$, while for 5 points it is $7.644 \mathrm{~m}^{3}$ and for 11 points it is $7.630 \mathrm{~m}^{3}$ (Figure 8), representing a percentage decrease of $\mathbf{4 . 8 7 8 \%}$ and $\mathbf{5 . 0 5 2} \%$ (Table 7) respectively.

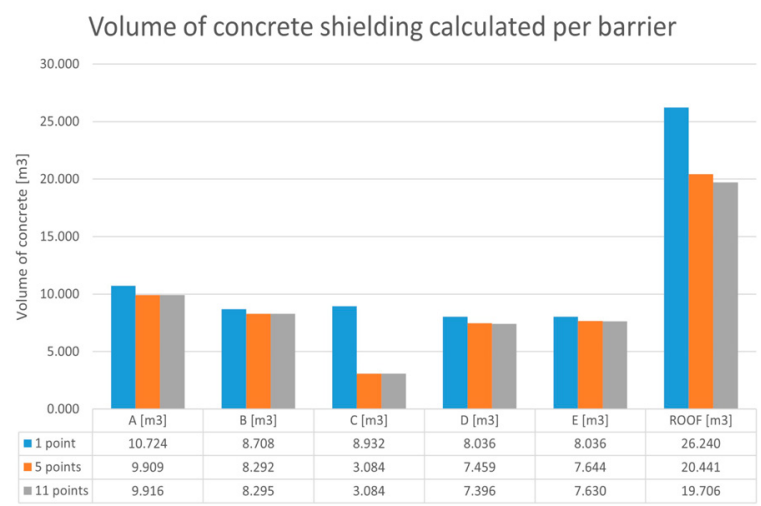

FIGURE 8 Comparison of the volume required per barrier.

In the case of barrier $\mathrm{C}$, it represents the best reduction in shielding, since a single point requires $8.932 \mathrm{~m}^{3}$ of concrete, while with the proposed method the volume required is $3.084 \mathrm{~m}^{3}$ (Table 8 ). This difference represents a $\mathbf{6 5 . 4 7 2 \%}$ of reduction in the shielding volume (Table 7).

TABLE 8. Shielding for barrier C.

\begin{tabular}{|c|c|c|c|c|c|c|c|c|}
\hline $\begin{array}{c}\text { Number } \\
\text { of points }\end{array}$ & Section & $\mathbf{x}$ & $\mathbf{y}$ & $\begin{array}{c}\mathbf{d} \\
{[\mathbf{m}]}\end{array}$ & $\begin{array}{c}\mathbf{E t} \\
{[\mathbf{m}]}\end{array}$ & $\begin{array}{c}\mathbf{a} \\
{\left[\mathbf{m}^{\mathbf{2}}\right]}\end{array}$ & $\begin{array}{c}\mathbf{a c} \\
{\left[\mathbf{m}^{2}\right]}\end{array}$ & $\begin{array}{c}\text { Volume } \\
{\left[\mathbf{m}^{3}\right]}\end{array}$ \\
\hline 1 & $\mathrm{dc}$ & 8.00 & 2.50 & 5.000 & 0.319 & - & - & 8.932 \\
\hline $\begin{array}{c}\text { First } \\
\text { section }\end{array}$ & 1 & 8.00 & 8.00 & 7.433 & 0.269 & 0.646 & & \multirow{2}{*}{0.881} \\
\hline $\begin{array}{c}\text { Second } \\
\text { section }\end{array}$ & 2 & 6.80 & 8.00 & 6.685 & 0.042 & 0.235 & & \\
\hline
\end{tabular}

For roof shielding, the volume required for one point is $26.240 \mathrm{~m}^{3}$ (Figure 8), meanwhile for 5 and 11 points, they were $20.441 \mathrm{~m}^{3}$ and $19.706 \mathrm{~m}^{3}$ respectively (Table 9), representing a reduction percentage of $\mathbf{2 2 . 1 0 0 \%}$ and $\mathbf{2 4 . 9 0 1 \%}$ respectively. 
TABLE 9. Armoring for the roof.

\begin{tabular}{|c|c|c|c|c|c|c|c|c|c|}
\hline $\begin{array}{l}\text { Number } \\
\text { of points }\end{array}$ & $\mathbf{N}^{\circ}$ & $\mathbf{x}$ & $\mathbf{y}$ & $\mathrm{z}$ & $\begin{array}{c}\mathbf{d} \\
{[\mathrm{m}]}\end{array}$ & $\begin{array}{c}\mathbf{E t} \\
{[\mathrm{m}]}\end{array}$ & \begin{tabular}{|c|} 
atr \\
{$\left[\mathrm{m}^{2}\right]$}
\end{tabular} & $\begin{array}{l}\mathrm{V}[\mathrm{tr}] \\
{\left[\mathrm{m}^{3}\right]}\end{array}$ & $\begin{array}{c}\text { Volume } \\
{\left[\mathrm{m}^{3}\right]}\end{array}$ \\
\hline \multirow{9}{*}{5} & 0 & 3.000 & \begin{tabular}{|l|l|}
0.000 \\
\end{tabular} & 3.500 & 3.466 & \begin{tabular}{|l|l}
0.364 \\
\end{tabular} & & & \multirow{9}{*}{20.441} \\
\hline & 1 & 3.000 & 2.000 & 3.500 & 2.452 & 0.410 & 0.774 & 4.334 & \\
\hline & 2 & 3.000 & 2.400 & 3.500 & 2.402 & 0.410 & 0.164 & 0.918 & \\
\hline & $\mathrm{dt}$ & 3.000 & 2.500 & 3.500 & 2.400 & 0.410 & 0.041 & 0.230 & \\
\hline & 2 & 3.000 & \begin{tabular}{|l|l|}
4.000 \\
\end{tabular} & 3.500 & 2.830 & 0.410 & 0.615 & 3.444 & \\
\hline & 3 & 3.000 & \begin{tabular}{|l|l|}
5.600 \\
\end{tabular} & 3.500 & 3.920 & 0.350 & 0.608 & 4.864 & \\
\hline & 4 & 3.000 & 6.000 & 3.500 & 4.244 & 0.338 & $\begin{array}{ll}0.138 \\
\end{array}$ & 1.104 & \\
\hline & 5 & 3.000 & 8.000 & 3.500 & 6.001 & 0.298 & 0.636 & 5.088 & \\
\hline & $\mathrm{dl}$ & 6.800 & 8.000 & 3.500 & $\begin{array}{l}7.103 \\
\end{array}$ & 0.034 & 0.082 & 0.459 & \\
\hline \multirow{13}{*}{11} & 0 & 3.000 & 0.000 & 3.500 & 3.466 & 0.364 & & & \multirow{13}{*}{19.706} \\
\hline & 1 & 3.000 & \begin{tabular}{|l|l}
0.800 \\
\end{tabular} & 3.500 & 2.941 & 0.383 & 0.299 & 1.674 & \\
\hline & 2 & 3.000 & \begin{tabular}{|l}
1.600 \\
\end{tabular} & 3.500 & 2.563 & \begin{tabular}{|l|l|}
0.410 \\
\end{tabular} & 0.317 & 1.775 & \\
\hline & 3 & 3.000 & 2.400 & 3.500 & 2.402 & \begin{tabular}{|l|l|}
0.410 \\
\end{tabular} & 0.328 & 1.837 & \\
\hline & $\mathrm{Dt}$ & 3.000 & 2.500 & 3.500 & 2.400 & 0.410 & 0.041 & 0.230 & \\
\hline & 4 & 3.000 & \begin{tabular}{|l|l}
3.200 \\
\end{tabular} & 3.500 & 2.500 & \begin{tabular}{|l|l|}
0.410 \\
\end{tabular} & 0.287 & 1.607 & \\
\hline & 5 & 3.000 & 4.000 & 3.500 & 2.830 & \begin{tabular}{|l|l|}
0.410 \\
\end{tabular} & 0.328 & 1.837 & \\
\hline & 6 & 3.000 & 4.800 & 3.500 & 3.324 & 0.383 & 0.317 & 1.775 & \\
\hline & 7 & 3.000 & \begin{tabular}{|l|l|}
5.600 \\
\end{tabular} & 3.500 & 3.920 & \begin{tabular}{|l|l}
0.350 \\
\end{tabular} & 0.293 & 2.344 & \\
\hline & 8 & 3.000 & 6.400 & 3.500 & 4.579 & 0.328 & 0.271 & 2.168 & \\
\hline & 9 & 3.000 & 7.200 & 3.500 & 5.277 & 0.311 & 0.256 & 2.048 & \\
\hline & 10 & 3.000 & \begin{tabular}{|l|}
8.000 \\
\end{tabular} & 3.500 & 6.001 & \begin{tabular}{|l}
0.298 \\
\end{tabular} & 0.244 & 1.952 & \\
\hline & $\mathrm{dl}$ & 6.800 & \begin{tabular}{|l|l|}
8.000 \\
\end{tabular} & 3.500 & \begin{tabular}{|l|l|}
7.103 \\
\end{tabular} & \begin{tabular}{|l|}
0.034 \\
\end{tabular} & 0.082 & 0.459 & \\
\hline
\end{tabular}

The calculation of the geometric mean of the reduction percentages per wall at 5 points yielded a reduction percentage of $\mathbf{1 1 . 0 7 0} \%$, while for 11 points it was $11.526 \%$.

In addition, the shielding volume required for the HDR-B room at one point is $70.676 \mathrm{~m}^{3}$, while for fractionation at 5 points requires $56.829 \mathrm{~m}^{3}$ and at 11 points $56.027 \mathrm{~m}^{3}$, representing a percentage decrease of $\mathbf{1 9 . 5 9 2} \%$ and $\mathbf{2 0 . 7 2 7 \%}$, respectively (Table $\mathbf{1 0 )}$ ).

TABLE 10. Percentage of total volume reduced by 5 and 11 points.

\begin{tabular}{|c|c|c|}
\hline $\begin{array}{c}\text { Number } \\
\text { of points }\end{array}$ & $\begin{array}{c}\text { Total volume } \\
{\left[\mathbf{m}^{\mathbf{3}}\right]}\end{array}$ & $\begin{array}{c}\text { Reduced volume } \\
{[\mathbf{\%}]}\end{array}$ \\
\hline 1 & 70.676 & - \\
\hline 5 & 56.829 & 19.592 \\
\hline 11 & 56.027 & 20.727 \\
\hline
\end{tabular}

It is important to mention that, currently the design methods for shielding a HDR-B room are determined in accordance with the reports of the NCRP (No. 49,
151, and 155) and IAEA SRS-47, which establish the calculation of shielding thickness starting from the closest points to the source [4] [10] [11] [25]. However, knowing that gamma-ray attenuation is related to the interaction with matter, represented by the Equation (10):

$$
I(x)=I(0) \cdot e^{-\mu x}
$$

Where $\mathrm{I}(\mathrm{x})$ is the intensity of gamma-rays as a function of distance $\mathrm{x}$ in the material and $\mu$ is the linear attenuation coefficient which depends on the energy of the gamma rays and the material which they interact with [26] [27], it is possible to compare an analysis based on fractionation of the barriers (proposed in Figure 3), derived from the fact that it is known that increasing the distance between the focal point (source) and the interaction point (dosimetric point) the amount of radiation is decreased by the inverse square law of the distance [7] [18] [26] [28] [29].

In this sense, a reduction in the volume of shielding was obtained in all barriers calculated with the proposed method (Figure 8), the most significant reduction percentage is $65.472 \%$ in the $\mathrm{C}$ barrier (Table 7 ). In the other barriers, the reduction was lower because the distances from the points to the source do not present much difference between them. One example is barrier $\mathrm{B}$, divided into 11 points (Table 6), most of the calculated distances (column $\mathrm{d}[\mathrm{m}]$ ) are within the range from 5.500 to $7.433 \mathrm{~m}$.

It is important to point out, according to Table 10, the volume calculated at 5 points $\left(56.829 \mathrm{~m}^{3}\right)$ is higher than at 11 points $\left(56.027 \mathrm{~m}^{3}\right)$; it can be inferred that the smaller the separation distance between the points, the higher the accuracy of the shielding calculation, since more intermediate points are considered. The most significant example is the roof, whose difference between the shielding volume calculated at 5 (is $20.441 \mathrm{~m}^{3}$ ) and 11 points $\left(19.706 \mathrm{~m}^{3}\right)$ is $0.735 \mathrm{~m}^{3}$ (Table 9). 
Also, IAEA document SRS-47 recommends that for HDR-B room the shielding barriers should be primary because when the source is in use, it is isotropic and without collimation [11] [17] [31] [33]. However, it was analyzed that both in the second section of the $\mathrm{C}$ barrier (Figure 5) and in the second section of the roof (Figure 7) there is no primary radiation, but the radiation transmitted through by the $\mathrm{E}$ barrier and the scattered radiation, product of the reflection on barrier B. Therefore, and considering the cost-benefit, it is possible to consider these sections as secondary barriers, otherwise; it implies calculating an excessively and unnecessary thickness, which implies the requirement of more material, space, and economic resources [30] [34] [35].

It should be noted that there is no specific recommendation or method for the analysis of secondary radiation. Even estimating the absorbed dose at the entrance of the maze is difficult, so in practice, various methods have been adopted, ranging from considering only direct radiation or scattered radiation ${ }^{[4]}[11]$.

In the case of the secondary radiation analysis, the value used for $\alpha$ corresponds to ${ }^{60} \mathrm{Co}$, because in the IAEA SRS-47 report, it is not available for ${ }^{192}$ Ir. In addition, ${ }^{60} \mathrm{Co}$ has a gamma-ray energy value (of $1.25 \mathrm{MeV}$ ) higher than that of ${ }^{192} \mathrm{Ir}(0.375 \mathrm{MeV})$, thus ensuring that the calculation is effective ${ }^{[11]}[26][36]$.

It is important to mention that this study does not contemplate the affectation of rear shielding derived from the elimination of part of it to install ducts and boxes embedded in walls, roofs and floors, hardware in lead-lined doors or concrete block joints, since these adaptations are specific to each HDR-B room [30] [37].

Similarly, it does not include the shielding analysis for the floor, because it is assumed that the HDR-B room is on the ground level does not affect any piping or drainage ${ }^{\text {[32] }}$. However, if necessary, it can be performed in the same way as for the roof.
Although the design of the HDR-B room is related to space and available resources, this method is intended as a strategy to reduce construction costs without failing to comply with national and international regulations regarding exposure dose limits for exposed personnel and the public, and also, to optimize resources to be allocated to other expenses such as the cost of equipment, radioactive sources, auxiliary equipment, service and maintenance costs, training and salaries of personnel [26] [31] [34] [37] [38].

In this sense, a cost-benefit analysis of the fractional shielding calculation could be expected to be effective in RP and cheaper in shielding material cost with respect to the IAEA SRS-47 methodology. However, the option of having an RP surveillance program is not ruled out [32] [34] [39].

As for the geometric mean calculated for the percentages reduced in each barrier (Table 7), it was obtained that, for the fractionation in 5 points, it was $11.070 \%$, meanwhile for 11 points it was $11.526 \%$. This indicates that the shielding reduction in the DHR-B room barriers is reduced by at least $11 \%$.

Thus, the proposed method for the calculation of shielding for HDR-B rooms, which starts from the RP and optimizes space and economic resources allocated, a concrete reduction of $19.592 \%$ and $20.727 \%$ was obtained for the fractionation in 5 and 11 points respectively (Table 10), which makes it more beneficial compared to conventionally method using the IAEA 47.

\section{CONCLUSIONS}

According to the results obtained and basing this model on the IAEA SRS-47 methodology, it is concluded that through the fractional calculation of shielding and the distinction of primary and secondary barriers, it is possible to reduce $19.592 \%$ and $20.727 \%$ of construction material for the fractionation 
in 5 and 11 points respectively, in a brachytherapy room with maze; optimizing costs without affecting the PR guidelines for exposed workers and public in adjacent areas.

This difference of percentage is related to the fractionation of the barriers, where the higher the fractionation, the higher the accuracy of the shielding calculation. This possible error is mitigated by including an HVL layer; however, an RP monitoring program is not rejected.

Finally, this study opens the way to be used in the design of shielding with other methodologies and in other areas with the use of ionizing radiation sources.

\section{AUTHOR CONTRIBUTIONS}

S.G.G. conceptualized the project, developed the methodology and writing of the manuscript. H.M.M.M. carried out formal analysis and writing of the final version of the manuscript. J.P.H. conceptualization of the project and designed and supervised development of the methodology writing of the manuscript. M.A.M.F. provided materials for the development of the research, supervised the development of the methodology, reviewed, and validated the final version of the manuscript. F.M.S. validated the methodology design and supervised the development of the methodology and provided materials and resources for the project. All authors reviewed and approved the final version of the manuscript. 


\section{REFERENCES}

[1] International Commission on Radiological Protection. Las Recomendaciones 2007 de la Comisión Internacional de Protección Radiológica [Internet]. Madrid: Sociedad Española de Protección Radiológica; 2007. 116p. Reporte No. 103. Available from: https:// www.icrp.org/docs/P103_Spanish.pdf

[2] International Atomic Energy Agency. Annual Report for 2004 [Internet]. Vienna: International Atomic Energy Agency; 2004. 89p. Report No. 2004. Available from: https://www.iaea.org/sites/default/ files/anrep2004_full.pdf

[3] International Atomic Energy Agency. Radiation Safety in Industrial Radiography. Specific Safety Guide No. SSG-11 [Internet]. Vienna: International Atomic Energy Agency; 2011. 104p. Report No. SSG11 Available from: https://www-pub.iaea.org/MTCD/Publications/ PDF/Pub1466_web.pdf/

[4] Perez-Calatayud J, Corredoira Silva E, Crispín Contreras V, Eudaldo Puell T, et al. Protección radiológica en Braquiterapia: Informe del grupo de trabajo de Braquiterapia de la SEFM. Rev Física Médica [Internet]. 2015;16(2):11-47. Available from: https:// revistadefisicamedica.es/index.php/rfm/article/view/175

[5] International Commission on Radiological Protection. Protección Radiológica en Medicina [Internet]. Ciudad Autónoma de Buenos Aires: Sociedad Argentina de Radioprotección; 2011. 64p. Publicación No. 105. Available from: https://www.icrp.org/ docs/P\%20105\%20Spanish.pdf

[6] International Atomic Energy Agency. Radiation Protection and Safety in Medical Uses of Ionizing Radiation [Internet]. Vienna: International Atomic Energy Agency; 2018. 318p. Specific Safety Guide No. SGG-46. Available from: https://www-pub.iaea.org/ MTCD/Publications/PDF/PUB1775_web.pdf

[7] Núñez M. Protección radiológica en Medicina Nuclear [Internet]. 2008; Available from: https://www.alasbimn.net/comites/tecnologos/ material/Proteccion_radiologica.pdf

[8] Reglamento General de Seguridad Radiológica [Internet]. 1988. Available from: https://www.gob.mx/cms/uploads/attachment/ file/122476/reglamento_general_seguridad_radiologica.pdf

[9] Eckerman K, Harrison J, Menzel HG, Clement CH. Compendium of Dose Coefficients based on ICRP Publication 60 [Internet]. International Commission on Radiological Protection; 2013. 130p. ICRP publication 119. Available from: https://www.icrp.org/ docs/P\%20119\%20JAICRP\%2041(s)\%20Compendium\%20of\%20 Dose\%20Coefficients\%20based\%20on\%20ICRP\%20 Publication\%2060.pdf

[10] National Council on Radiation Protection and Measurements. Structural Shielding design and evaluation for medical use of $\mathrm{x}$ rays and gamma the rays of energies up to $10 \mathrm{MeV}$. Washington: National Council on Radiation Protection and Measurements; 1998. 113p. Report No. 049.

[11] International Atomic Energy Agency. Radiation Protection in the design of Radiotherapy Facilities [Internet]. Vienna: International Atomic Energy Agency; 2006. 130p. Safety Reports Series No. 47. Available from: https://www-pub.iaea.org/MTCD/Publications/PDF/ Pub1223_web.pdf

[12] Turner JH. An introduction to the clinical practice of theranostics in oncology. Br J Radiol [Internet]. 2018;91(1091):20180440. Available from: https://dx.doi.org/10.1259\%2Fbjr.20180440
[13] Montemaggi P, Trombetta M, Brady LW. Brachytherapy, an International Perspective [Internet]. Springer; 2016. 408p. Available from: https://doi.org/10.1007/978-3-319-26791-3

[14] Pallaroso Yela MA. Efecto del material de contraste en las ditribuciones de dosis asociadas a la braquiterapia de Alta Tasa con Iridio-192 para tratamientos de cáncer cérvico-uterino [Internet]. [Master's thesis]. [Quito]: Escuela Politécnica Nacional, 2018. 73p. Available from: https://bibdigital.epn.edu.ec/ bitstream/15000/19490/1/CD-8888.pdf

[15] Medina Mendieta SM. Puesta en servicio clínico de la unidad de Braquiterapia de alta tasa de dosis con fuente de 60 Co SagiNova; en el Centro Nacional de Radioterapia "Nora Astorga" en el periodo de marzo -abril 2018 [Internet]. [dissertation]. [Managua]: Universidad Nacional Autónoma de Nicaragua, Managua, 2019. 93p. Available from: https://repositorio.unan.edu.ni/12539/1/ MONOGRAFIA\%2OSARAY\%2OMEDINA\%2OMENDIETA.pdf

[16] Yanchapanta Bastidas VN. Metodología para adaptar recintos de irradiación de braquiterapia HDR con Ir-192 a Co-6o[Internet]. [Master's thesis]. [Mendoza]: Universidad Nacional de Cuyo, 2016. 80p. Available from: http://ricabib.cab.cnea.gov. ar/571/1/1Yanchapanta.pdf

[17] International Atomic Energy Agency. Radiotherapy facilities: Master planning and concept design considerations. Vienna: International Atomic Energy Agency; 2014. 31p. Human Health Reports No. 10.

[18] Saravia-Rivera GE. Protección y seguridad radiológicas. Anal Radiol Mex [Internet]. 2013;2:105-110. Available from: https://www. medigraphic.com/pdfs/anaradmex/arm-2013/arm132g.pdf

[19] American Association of Physicists in Medicine. Specification of brachytherapy sourse strength[Internet]. New York: American Association of Physicists in Medicine; 1987. 21p. Report No. 21. Available from: https://www.aapm.org/pubs/reports/rpt_21.pdf

[20] Brachytherapy V. Equipo de carga diferida HDR GammaMedplus iX, 3/24 iX.[Internet]. Varian. Available from: https://www.varian. com/es/products/brachytherapy/afterloaders-applicators/ gammamedplus-ix

[21] Tinoco G. Antecedentes: Distancia entre dos puntos [Internet]. UAEM; 2013. Available from: $h t t p: / / m e t a b a s e . u a e m . m x: 8080 /$ bitstream/handle/123456789/2883/1_Antecedentes-Distancia\%20 entre\%20dos\%20puntos.pdf?sequence $=1$

[22] Flores Martínez P. El trapecio isóceles de diagonales perpendiculares [Internet]. Universidad de Granada. Available from: http://www.ugr.es/ pflores//textos/aRTICULOS/Propuestas/ trapecio.pdf\#: :text=Caracter\%C3\%ADsticas\%20del\%20trapecio\%20 de\%20diagonales\%20perpendiculares\%20Seg\%C3\%BAn\%20 las,dos\%20tri\%C3\%A1ngulos\%20rect\%C3\%A1ngulos\%20e\%20 is\%C3\%B3sceles\%2C\%20y\%20dos\%20tri\%C3\%A1ngulos

[23] Salazar, C, y Del Castillo S. Fundamentos Básicos De Estadística. 2018. 224p.

[24] Vargas Sabadìas A. Estadística descriptiva e inferencial. Murcia:Universidad de Castilla-La Mancha; 1995. 576p.

[25] National Council on Radiation Protection and Measurements. Structural Shielding Design and Evaluation for Megavoltage X- and Gamma-Ray Radiotherapy Facilities. Bethesda: NCRP; 2005. Report No. 151. 
[26] Cherry R. Radiaciones ionizantes. In: Enciclopedia de salud y seguridad en el trabajo[Internet]. 2010. Available from: https:// www.insst.es/documents/94886/162520/Cap\%C3\%ADtulo+48.+Radia ciones+ionizantes

[27] Ghiasi H, Mesbahi A. A new analytical formula for neutron capture gamma dose calculations in double-bend mazes in radiation therapy. Reports Pract Oncol Radiother [Internet]. 2012;17:220225. Available from: https://doi.org/10.1016/j.rpor.2012.03.011

[28] Delgado Ramos O, Fernández Frededs O, Leyton Legues F, Rodríguez Casas AM, et al. Manual de protección radiológica y de buenas prácticas en radiología dento-maxilo-facial [Internet]. Chile: Instituto de Salud Publica de Chile;82p. Available from: https://www.minsal.cl/portal/url/item/7f2d789a9750153be04001011 fo12d29.pdf

[29] Preciado Ramírez M, Luna Cano V. Medidas Básicas de Protección Radiológica. Cancerología. Cancerología [Internet]. 2010;5(2010):25-30. Available from: http://incan-mexico.org/ revistainvestiga/elementos/documentosPortada/1294860259.pdf

[30] Horton P, Eaton D. Desing and Shielding of Radiotherapy Treatment Facilities [Internet]. Philadelphia: IOP Publishing; 2013. 304p. Available from: https://doi.org/10.1088/978-0-7503-1440-4

[31] International Atomic Energy Agency. Setting Up a Radiotherapy Programme: Clinical, Medical Physics, Radiation Protection and Safety Aspects [Internet]. Vienna: International Atomic Energy Agency; 2008. 255p. Available from: https://www-pub.iaea.org/ MTCD/Publications/PDF/pub1296_web.pdf

[32] Australian Radiation Protection and Nuclear Safety Agency. Radiation Protection in Radiotherapy [Internet]. Barton: Acting Chief Executive Officer of ARPANSA; 2008. 106p. Radiation Protection Series Publication No. 14.3. Available from: https://www. arpansa.gov.au/sites/default/files/legacy/pubs/rps/rps14_3.pdf

[33] International Atomic Energy Agency. Radiation Oncology Physics: A Handbook for Teachers and Students [Internet]. Vienna: International Atomic Energy Agency; 2005. 657p. Available from: https://www-pub.iaea.org/mtcd/publications/pdf/pub1196_web.pdf
[34] International Atomic Energy Agency. Implementation of High Dose Rate Brachytherapy in Limited Resource Settings [Internet]. Vienna: International Atomic Energy Agency; 2015. 97p. Human Health Series No. 30. Available from: https://www-pub.iaea.org/ MTCD/Publications/PDF/Pub1670web-5444797.pdf

[35] Jalbert M. Intensity Modulation of Medium-Energy, High Dose Rate Intensity Modulation of Medium-Energy, High Dose Rate Brachytherapy Sources Brachytherapy Sources [Internet]. [dissertation]. [Worcester]: Worcester Polytechnic Institute, 2020. 27p. Available from: https://digital.wpi.edu/pdfviewer/8049g7500

[36] International Atomic Energy Agency. Protección radiológica y seguridad de las fuentes de radiación: Normas básicas internacionales de seguridad [Internet]. Vienna: International Atomic Energy Agency; 2011. 280p. N GSR Part 3. Available from: https://www-pub.iaea.org/MTCD/Publications/PDF/ SupplementaryMaterials/SupM_Pub1531_Spanish.pdf

[37] Arwui CC, Schandorf C, Nani K, Darko EO, et al. Shielding design of a brachytherapy unit at the Korle Bu teaching hospital in Ghana: Comparison of theoretical calculations and experimental study. Radiat Prot Dosimetry [Internet]. 2010;140:59-66. Available from: https://doi.org/10.1093/rpd/ncq001

[38] American Association of Physicists in Medicine. Remote Afterloading Technology [Internet]. New York: American Institute of Physics; 1993. 107p. Report No. 41. Available from: https://www. aapm.org/pubs/reports/rpt_41.pdf

[39] Van Den Broek JG, Weatherburn H. Re-evaluation of a radiation protection cost benefit analysis study in brachytherapy. Br J Radiol [Internet]. 1994;67:59-62. Available from: https://doi. org/10.1259/0007-1285-67-793-59 